\title{
The interplay of language ideologies and contextual cues in multilingual interactions: Language choice and code-switching in European Union institutions
}

\author{
R U T H W O D A K \\ Department of Linguistics and English Language, Lancaster University \\ County South, Lancaster LA1 4YL, UK \\ r.wodak@lancaster.ac.uk \\ M I C H A $Ł \quad K R Z$ Y Ż A N O W S I \\ School of English, Adam Mickiewicz University \\ Al. Niepodległości 4, 61-874 Poznań, Poland \\ mkrzyzanowski@ifa.amu.edu.pl \\ B E R N H A R D F O R C H T E R \\ Institute of Social Sciences, Humboldt-Universität zu Berlin \\ Philosophische Fakultät III, Unter den Linden 6, 10099 Berlin, Germany \\ b.forchtner@hu-berlin.de
}

A B S T R A C T

This article analyzes multilingual practices in interactions inside European Union (EU) institutions. On the basis of our fieldwork conducted in EU organizational spaces throughout 2009, we explore different types of communication in order to illustrate how Members of the European Parliament (MEPs) and officials at the European Commission practice and perform multilingualism in their everyday work. In our theoretical and methodological framework, we draw on existent sociolinguistic ethnographical research into organizations and interactions, and integrate a multilevel (macro) contextual and sequential (micro) analysis of manifold data (observations, field notes, recordings of official and semi-official meetings, interviews, etc.). In this way, a continuum of context-dependent multilingual practices becomes apparent, which are characterized by different patterns of language choice and which serve a range of both manifest and latent functions. By applying the Discourse-Historical Approach (DHA) of Critical Discourse Studies (CDS), the intricacies of the increasingly complex phenomenon of multilingualism in transnational-organizational spaces, which are frequently characterized by diverse power-related and other asymmetries of communication, can be adequately coped with. (Code-switching, 
multilingualism, power, institutional spaces, European Union, ethnography, discourse-historical approach, critical discourse studies)*

\section{INTRODUCTION: A IMS A N D O B JECTIVES}

In this article, based on fieldwork conducted throughout 2009 at the European Parliament (EP) and the European Commission (CEC), we explore the multilingual practices and related dynamics in institutional interactions inside the organizations of the EU. ${ }^{1}$ There, different levels of multilingual communication, including semiofficial communication (at the EP) and internal "everyday" communication (at the CEC), were observed and recorded, illustrating how these institutions practice multilingualism in their professional everyday work.

Drawing on the results of multilevel analyses of thirty-six meetings observed at the CEC and the EP, we focus on two qualitative case studies: a closed meeting in one of the Directorates General of the CEC and a publically accessible sitting of one of the Committees of the EP. Through our analysis, we challenge the dichotomy that is often stated in the literature between "distinctly monolingual" and "distinctly multilingual" language practices and policies (Ammon 2006; Auer \& Wei 2007). In contrast, we claim that, in the EU context, we are dealing with A SET OF DIFFERENT MULTILINGUAL PRACTICES CHARACTERIZED BY CONTEXT-DEPENDENT LANGUAGE CHOICES AND PATTERNS OF CODE-SWITCHING (CS) THAT CAN BE FACILITATED AND TRIGGERED BY A PLETHORA OF FACTORS. Furthermore, we also claim that the concept of GENRE has been neglected in much of the research on multilingual practices and CS (Wodak 2008), although a specific genre most certainly contributes to occurrences of CS, and we subsequently focus especially on "what people do by code-switching" (Auer 2010:469).

Our theoretical point of departure is that language use is an element central to constructing domination in organizational settings and that those forms that carry legitimacy favor particular kinds of knowledge (Heller 2003). We agree with Heller (1995:374), who argues that "examining language practices can therefore reveal the micro-processes of symbolic domination," and claim that even interactional and structural micro-processes such as CS are never arbitrary or neutral (Heller 1995:374) but are linked to wider power struggles (Blackledge \& Creese 2010). This focus on the salience of power in interaction and communication relates to general principles of critical research into language and communication (see below; Duchêne 2008; Wodak \& Meyer 2009b).

The research questions that guide our work include:

- How are language repertoires shaped inside EU institutions (also in relation to official, general, and institutionally specific regulations)?

- Who/What determines language choice and code-switching in interactions in EU organizational spaces (both front- and backstage)? 
- And on a more general level: Is multilingualism an essential part of the EU's "diversity"?

Inspired by the recent interest in ethnographic work on language and communication - especially in a variety of post- and neo-Hymesian approaches (cf., inter alia, Rampton, Tusting, \& Maybin 2007) — as well as building on research in the areas of sociolinguistic, linguistic, and organizational anthropology and critical discourse studies (CDS), we simultaneously analyse co- and contexts of multilingual practices in order to explain, understand, and evaluate how participants PERFORM MULTILINGUALISM in its manifold forms. We believe that - depending on specific contextual cues as well as on structural constraints - different micro and macro LANGUAGE IDEOLOGIES co-determine multilingual practices. In this way, we establish a typology of both relevant phenomena, which facilitate CS, as well as contexts for language choice (and CS), in the overall framework of EU internal language repertoires.

Our approach to multilingualism in EU institutional spaces follows a broadly defined ethnographic perspective, the so-called Anthropology of the European Union (Bellier \& Wilson 2000; cf. also Krzyżanowski 2011), which originates from a variety of French, American, and British anthropological traditions of organizational research. Anthropological examination of the EU treats the Union's key institutions - including the European Commission (cf. Abélès, Bellier, \& McDonald 1993; Abélès 2000; Bellier 2000; Shore 2000) and the European Parliament (cf. Abélès 1992; Abélès et al. 1993) — as THE microcosm of Europe and as constantly evolving dynamic organizational contexts. Not only, they argue convincingly, are policies for Europe being produced in these institutions; the political, cultural, linguistic, and otherwise understood diversity of Europe is also (supposed to be) reflected and negotiated. As illustrated in our previous studies, which were inspired by these approaches (cf. Muntigl, Weiss, \& Wodak 2000; Wodak 2000, 2009; Krzyżanowski \& Oberhuber 2007; Krzyżanowski 2010), research into EU institutions at the intersection of ethnography and CDS allows for an in-depth exploration of discursive and communicative practices of the latter.

In the following, we first outline a set of theoretical considerations that underpin our analysis. We briefly introduce relevant aspects of the Discourse Historical Approach (DHA) in CDS as well as its take on central notions such as "discourse as social practice," "genre," and "power." Moreover, we focus on code-switches as performances that are ideologically shaped and reliant on unequally distributed (linguistic) resources (as exemplified in the work of Monica Heller). Secondly, we present our specific approach to ethnography by showing how it is defined and analytically mobilized throughout our research. This includes a detailed description of context, that is, of the European Union institutions: their internal regimes of multilingualism and their institutionally specific "guiding" language ideologies and language use. Thirdly, qualitative analyses of transcribed meeting data illustrate the manifold functions and meanings of context-dependent occurrences of CS in different types (subgenres) of meetings. Finally, we discuss what these results 
imply for current theories of multilingualism in general, and for the EU's multilingual repertoires more specifically.

THEORETICA L C ONS IDER A TIONS

The Discourse Historical Approach: Defining discourse, genre, power, and context

In this article we apply some of the central premises of DHA, which, since its emergence in the early 1990s (cf. Reisigl \& Wodak 2001, 2009; Wodak \& Meyer 2009a), has become one of the main currents within CDS.

In DHA, "discourse" is not viewed as simply determining social action but also as integrating a voluntaristic element. These two aspects are intertwined or, as Fairclough \& Wodak (1997:258) put it, discourse (and SEMIOSIs in general) is:

a form of 'social practice'. Describing discourse as a social practice implies a dialectical relationship between a particular discursive event and the situation(s), institution(s) and social structure(s), which frame it. ... To put the same point in a different way, discourse is socially CONSTITUTIVE as well as socially shaped.

Furthermore, DHA proposes a multilevel definition of context in which we differentiate between:

- "the immediate language or text's internal co-text and co-discourse

- the intertextual and interdiscursive relationship between utterances, texts, genres, and discourses

- the extralinguistic social variables and institutional frames of a specific 'context of situation'

- the broader sociopolitical and historical context, which the discursive practices are embedded in and related to." (Reisigl \& Wodak 2009:93)

These distinctions facilitate investigating discourse, genres, and texts at different levels of functioning and realization. Thus, such a notion of context has clear implications for our research strategy in which we triangulate between different levels and datasets in order to study multilingual practices and their genre- and contextspecific differences.

In addition, the notion of "genre" plays a salient role in our study. While a variety of definitions exist (cf. Swales 1990; Bhatia 1993; Martin \& Rose 2008), we follow Bahktin's (1986:60) words that "[e]ach separate utterance is individual, of course, but each sphere in which language is used develops its own relatively stable types of these utterances. These we may call speech genres." This approach to genre is taken up and elaborated by Fairclough (1992:126) who defines genre as a "relatively stable set of conventions that is associated with, and partly enacts, a socially ratified type of activity." In other words, particular discursive practices, like other social activities, follow particular GENRE-INHERENT sets of rules. In this article, we 
focus mainly on the analysis of meetings in organizational spaces as our main genre. Meetings are - in general — increasingly perceived as sites where organizing and strategic change takes place (Kwon et al. 2009). ${ }^{2}$

In our fieldwork in the EP and CEC, we observed two distinctly different sites that condition institutionally specific subgenres of the MEETING-GENRE: On the one hand, INTERNAL meetings in the EC are clearly conversational. Although they are also run according to minutes and/or agendas, the latter delineate the content rather than the actual interactive and other conduct of encounters. On the other hand, semiplenary meetings at the EP are strictly organized and have clear rules and hierarchies. For example, the chair determines speaking times, turn-taking, and so on.

Boden (1994:82) observed that meetings "play an oddly central role in the accomplishment of the organization," while Mumby (1988:68) claimed that meetings "function as one of the most important and visible sites of organisational power, and of the reification of organisational hierarchy." In the context of this study, we view power not as a discrete entity but as a relational process that is inherently tied to communicative practices (Fairclough 1989). In several previous studies of interactions in EU institutional spaces from a CDA-ethnographic perspective, Krzyżanowski (2010, 2011) and Krzyżanowski \& Oberhuber (2007) were able to trace, in detail, the impact of subtle and explicit power mechanisms. The latter, also defined as mainstReAm voICE, allow more powerful players to emphasize their positions while simultaneously influencing the overall visions and ideas communicated within given organizations (cf. also Wodak 2000, 2009; Hardy \& Philips 2004).

Drawing on research by Boden (1994), the 'Language in the workplace' project in New Zealand (Stubbe, Lane, Hilder, Vine, Vine, Marra, Holmes, \& Weatherall 2003; Vine 2004), and Bargiela-Chiappini \& Harris's (1997) study of Italian and English corporate discourse, four linguistic strategies can be seen to underpin participants' level of involvement in organizational meetings and, thus, to express, negotiate, and determine power relations: (i) their MODE OF PARTICIPATION (or, in CA terms, their participation framework); (ii) the degree to which they are allowed to speak and have 'ACCESS TO THE FLOOR'; (iii) their MODE OF SELF-PRESENTATION enacted in interaction; and (iv) their DEGREE OF CONTROL OVER INTERACTION. The single most basic factor affecting individual involvement is the mode of participation in a meeting. A second aspect of involvement is the degree to which individuals have access to the floor to speak. Studies of gendered workplace participation have found, for example, that the distribution of talk and negotiation of access to the floor helps construct professional identities and power relations (Holmes 1992).

In the analysis below, we use some of these categories to analyze performances of CS relating to interruptions occurring in our data. A final important dimension of analyzing meetings is that of examining the extent to which interaction is constrained or enabled by techniques of control over the interaction. Here, we claim that patterns of control will lead to choices of more prestigious language, according 
to the concept of HEGEMONIC MULTILINGUALISM (cf. Krzyżanowski \& Wodak 2010). This can operate via two main linguistic-interactive means: (i) management of the meeting by the chair by formulating the agenda and controlling floor-taking by, and interactions between, the participants; and (ii) the discursive structure that might typify different types of meeting, that is, different subgenres (Holmes \& Stubbe 2003; Wodak et al. 2011). In our qualitative case studies below, we illustrate in which ways CS and language choices correlate and interact with specific strategies of involvement, meeting management, and control, which manifest themselves through a range of linguistic and pragmatic devices.

Finally, we briefly explore the notion of "power" - and its (mis)use-as the interactions in meetings are hugely influenced by power relations; hence, occurrences of CS are necessarily also linked to specific power constellations. Moreover, the two meeting subgenres inherently allow for different manifestations of power. We distinguish three modes of exercising power in discourse. Following Holzscheiter (2005:69), we view POWER IN DISCOURSE as actors' struggles with different interpretations of meaning. This struggle for "semiotic hegemony" relates to the selection of "specific linguistic codes, rules for interaction, rules for access to the meaning-making forum, rules for decision-making, turn-taking, opening of sessions, making contributions and interventions" (ibid.). POWER OVER DISCOURSE is defined as the general "access to the stage" in macro and micro contexts (Holzscheiter 2005:57), that is, processes of inclusion and exclusion. Finally, POWER OF DISCOURSE relates to "the influence of historically grown macro-structures of meaning, of the conventions of the language game in which actors find themselves" (ibid.). The individual influence of actors might contribute to changing these macrostructures (cf. also Wodak 2009). Power struggles are obviously not always related to observable behavior. In the specific meetings analyzed below, we encounter all modes of establishing/negotiating power, among other things through performing CS.

Thus, we argue that a detailed analysis of interaction in institutional settings needs an approach that accounts for power in/over/of discourse, always embedded in specific organizational contexts. ${ }^{3}$ In the following, we focus on some salient indicators of involvement and power negotiation in meetings, which — we claim — are part and parcel of a POLITICS OF CODE-SWITCHING and of PERFORMING MULTILINGUALISM and which we illustrate in our case studies below.

\section{Performing code-switching}

Traditionally, CS has been defined as "the use of several languages or sociolects in the same conversation or sentence" (Gardner-Chloros 2009:4) whereby:

motivation to code-switch relies on factors independent of the varieties as such, including the speakers' relative competence and that of their interlocutors, the identities they can express through each language, or the acceptability of CS in their network and in particular contexts. (Gardner-Chloros 2009:42) 
The conversation-analytical approach to CS has consistently argued against "the presupposition that the codes have a meaning which is independent of the local context in which they are used" (Auer 2010). ${ }^{4}$ Accordingly, participants - and not external categories imposed by the analyst - define what actually counts as CS, stressing the significance of sequential order in contrast to sociopolitical dimensions such as ideology, power, authority, prestige, or gender. ${ }^{5}$ For example, a speaker's identity is seen as salient only with respect to how this identity is actually performed in the interactive microcontext of a conversation (Antaki \& Widdicombe 1998). In line with this, Auer (2010:467; cf. also Auer 1998) states that "the term code-switching will be reserved for cases in which the juxtaposition of two codes (languages) is perceived and interpreted as a locally meaningful event by participants."

While we remain sceptical about a solely participant-oriented approach, we nevertheless agree with this focus on CS as meaningful social action. However, following our approach to power as presented above, we also believe that CS occurs in interdependence with a particular setting and with different resources. This relates well to Heller's (2007b:1) “critical sociolinguistics," which views CS as moving:

away from a focus on the whole bounded units of code and community, and towards a more processual and materialist approach which privileges language as a social practice, speakers as social actors and boundaries as products of social action.

Heller (1995:166) perceives these practices as inherently political in that they rely on different degrees of sociopolitical legitimacy and prestige associated with particular resources. In other words, "people mobilize what they have access to within the constraints of the discursive spaces in which they operate" (Heller 2007a:651). As a "set of ideologically-defined resources and practices" (Heller 2007b:2), language use is embedded in a web of power relations and placed in the context of "the speech economy of a multilingual community and of the verbal repertoires of individual members of that community" (Heller 1988:1). Consequently, questions such as "Who has access to valued linguistic resources," "Why are certain linguistic codes valued at all?" and "[H] ow linguistic resources are ordered in the context of historically contingent forms of social organisation" (Heller 1995:176) arise. It is therefore obvious how salient the control over regimes of $\mathrm{CS}$ could potentially be as the latter might become an important means "for achieving social, economic and political goals" (Heller 1995:165).

Accordingly, we link DHA with theories on CS which perceive the latter not as naturally occurring systems, but as embedded in interaction (Alvarez-Cáccamo 1998) and thus performed. As research on bi- or multilingualism has recently moved away "from an emphasis on languages and their different codes towards an account that describes the individual as engaged in meaning-making and identity work" (Blackledge \& Creese 2010:31), CS is increasingly defined as a discursive practice which is influenced by existing power relations such as the distribution 
of (linguistic) resources and the legitimacy of various knowledges in different discursive spaces (Heller 2007a). We endorse this view and believe that the peculiarity of the complex institutional spaces of the EU necessitates a closer look at CS, especially in terms of its performative aspects and "speakers draw[ing] on linguistic resources which are organized in ways that make sense under specific social conditions" (Heller 2007b:1). For this reason, we do not propose a reified notion of code and code-switching but rather approach CS as dynamic manifestation(s) of power and other related phenomena in institutional spaces.

\section{E T H N O R A P H Y F M U L T L I N G A L IS M IN E U I N S T I T U T I O N A L S P C E S}

Our research into EU multilingualism revolves around fieldwork in the above-mentioned institutional spaces and can thus be viewed as SOCIOLINGUISTIC ETHNOGRAPHY, that is, "a close look at language practices in a specific setting" (Heller 1999:1415). In our case, such ethnography is centred on the technique of ETHNOGRAPHIC OBSERVATION (Krzyżanowski \& Oberhuber 2007), a process of gathering inside knowledge about institutional practices by focusing on "actions undertaken by individual and collective actors in the observed (institutional) milieus" (Krzyżanowski \& Oberhuber 2007:48). Choosing ethnographic observations as our central technique allows us to avoid the traditional dilemma of participant or nonparticipant observation and to mediate between different degrees of our (researchers') involvement (cf. Gobo 2008).

In this article, we primarily view ethnography as an intricate and complex process that guides our research across the four different levels of context that we presented above. Thus, our definition of ethnography goes beyond its common definition as "fieldwork" or as just a "method" or "data-collection technique" (cf. Hammersley 1992). Instead, we follow the approach taken by Brewer (2000:11) who argues that "ethnography is not one particular method of data-collection but a style of research that is distinguished by its objectives, which are to understand the social MEANINGS and activities of people in a given 'field' or setting" (emphasis in the original). Hence, we see ethnography as a complex and ordered, though not necessarily linear, research process that informs our work throughout the duration of our study. Ethnography is thus analytically mobilized in our work as an overall framework that allows us to triangulate between a set of stages of analytical research and between different sets of data (genres, publics) (for a similar approach, cf. Heller 2001). The major stages - which explore different levels of context in a macro to micro order-include:

(a) IN-DEPTH PRE-FIELDWORK CONTEXTUALIZATION of our object of research by exploring our own and others' prior knowledge of the EU and its multilingualism, as well as of the EU-institutional contexts in question, including their focal modes, patterns, practices and "guiding" ideologies of multilingualism (cf. 
sections on The Broad context: Multilingualism in the EU institutions and The narrow context: European Commission, European Parliament, their LANGUAGE REGIMES AND IDEOLOGIES);

(b) ETHNOGRAPHIC OBSERVATIONS OF THE STUDIED CONTEXTS both from the point of view of their general patterns of communication and multilingualism and of the selected meetings - in order to validate the context-relevant information gathered prior to the analyses drawing on contextualization (cf. ETHNOGRAPHIC FIELDWORK AT THE CEC AND THE EP);

(c) IN-DEPTH QUALITATIVE ANALYSIS OF MEETINGS via a combination of discourse-historical and sociolinguistic analysis while focusing on issues such as power, communicative asymmetries, and so on (cf. IN-DEPTH ANALYSIS OF SELECTED MEETINGS (CASE STUDIES)).

By integrating findings from these different stages, our research aims to adopt a reflexive stance that is indispensable for ethnographic endeavors in which boundaries of interaction between "subjects" and "objects" of research are frequently difficult to delineate (cf. Davies 1999).

\section{The broad context: Multilingualism in the EU institutions}

All major language regulations within EU institutions derive their foundations from Regulation No. 1 of the European Council (1958), which stipulates that each member state of the European (Economic) Community (the antecedent of the EU prior to its creation in 1993) brings with it its own official language into the organization. The official languages of the EC/EU are also their working languages. This implies that — unlike in the UN (Phillipson 2003; Nic Craith 2006) - the EU should not differentiate between languages and that the major institutions of the Union in particular should operate a policy of equality between official and working languages.

Currently, there are twenty-three official EU languages, with each EU enlargement to date resulting in new official/working languages (see Table 1), and in turn leading to debates about the growing linguistic repertoire in EU organizations. Such debates began as early as 1973 (British, Danish, and Irish accession to the EC) when it was discussed-eventually to the detriment of Irish-whether Gaelic should become an official language since English is also an official language of Ireland (Irish did eventually become an official EU language in 2007). 1973 also saw the first (so-called "Danish") proposal on limiting the number of official languages (van Els 2005). Later enlargements, particularly the "grand" one by ten Eastern and Southern European countries (2004), triggered debates about whether: (i) each of the acceding states should bring their official language into the EU, given the huge differences in the numbers of their speakers (e.g. Polish vs. Maltese), and (ii) whether the "new" languages should have the same rights as those enjoyed by the "old" EU member states. 
TABLE 1. EU enlargements and official languages (1958-2007).

\begin{tabular}{|c|c|c|}
\hline Year & Acceding States & Incoming Official Languages \\
\hline 1958 & $\begin{array}{l}\text { Belgium, France, Germany, Italy, Luxembourg, } \\
\text { the Netherlands }\end{array}$ & Dutch, Italian, German, French \\
\hline 1973 & Denmark, Ireland, UK & Danish, English \\
\hline 1981 & Greece & Greek \\
\hline 1986 & Portugal, Spain & Portuguese, Spanish \\
\hline 1995 & Austria, Finland, Sweden & Finnish, Swedish \\
\hline 2004 & $\begin{array}{l}\text { Cyprus, Czech Republic, Estonia, Hungary, } \\
\text { Latvia, Lithuania, Malta, Poland, Slovakia, } \\
\text { Slovenia }\end{array}$ & $\begin{array}{l}\text { Czech, Estonian, Hungarian, Latvian, } \\
\text { Lithuanian, Maltese, Polish, Slovak, } \\
\text { Slovene }\end{array}$ \\
\hline 2007 & Bulgaria, Romania & Bulgarian, Irish, Romanian \\
\hline
\end{tabular}

Whereas EC Regulation No. 1 provides a general principle for official/working languages for the entire $\mathrm{EU}$, it also allows for institutionally specific interpretations of that rule. According to that provision, and depending on their definition of "specific cases" and their own needs, key EU institutions mold their internal rules of everyday functioning (stipulated in such documents as "rules of procedure" or "codes of conduct") and their own linguistic repertoires differently (cf. Wodak \& Krzyżanowski 2011 for further details).

While according to EC Regulation No. 1 official and working languages should not be differentiated at all, already our previous research illustrates that the EU institutions have progressively moved towards narrowing their linguistic repertoires. In a process that we label HEGEMONIC MULTILINGUALISM (Krzyżanowski \& Wodak $2010^{6}$ ), a set of "traditional working languages" (mainly English, French, or German) is, de facto, replacing the plurality of the twenty-three languages in the EU. Hence, a few EU working languages are given preference over other EU working languages, thus constituting a set of "core languages," which are ideologically preferred (or more frequently used). This implies salient consequences for democratic participation and representation and hinders the development of a public image of the EU institutions as being inclusive and multilingual.

\section{The narrow context: European Commission, European}

\section{Parliament, their language regimes and ideologies}

The largest and one of the oldest institutions of European integration - that is, the European Commission (CEC, previously also known as the Commission of the European Communities) - is the EU's public administration and executive power, which oversees the implementation of the Union's policies in different fields. It is led by the Commission President and a college of (currently) twentysix Commissioners, each responsible for a single or combined policy portfolio. Internally, the Commission is organized within a set of Directorates General 
(DGs) that are responsible for different policies, external relations, and internal as well as general services. The CEC is based in both Brussels and Luxembourg, with representative field offices across all twenty-seven EU member states.

The European Parliament (EP) by contrast is the only directly elected EU institution and is the Union's key legislative power that also has the ability to confirm or remove from office certain key EU officials. Over 730 members of the EP (MEPs) are gathered in European-level political groupings known as "the political families." MEPs are elected for five-year terms via a universal suffrage which applies across all EU Member States. The EP operates between two sites-the major one in Brussels and the official one in Strasbourg (Wodak 2009).

The CEC and the EP are salient not only for the everyday functioning of the EU but also for their contacts with the twenty-seven European member states and their citizens (cf. Krzyżanowski 2012). However, the two institutions also remain very different in their degrees of openness and accessibility. The CEC, as an administrative body, is difficult to access with the majority of the DGs being reluctant to communicate with the external world other than via the official CEC spokesperson service. As a strictly political institution, the EP remains (reasonably) open to the broader public (who can in principle access all plenary and official EP committee meetings), also as a function of contacts with MEPs' constituencies and potential voters.

Within the two institutions, one can also observe significant differences between the ways in which their patterns of "internal" multilingualism are regulated and practiced. The CEC officially operates a policy whereby all official instances of communication are in fact conducted in all official languages (European Commission 2000). Members and officials of the Commission traditionally use English, French, and (much less) German in their oral communication (particularly at a semiofficial level). Among those languages, French traditionally used to be the leading one, though recently English has clearly been gaining in importance. The EP, however, stipulates in its rules of procedure (Rule 138: Languages) that "all documents of the Parliament shall be drawn up in the official languages" (European Parliament 2004:66) and that, in plenary sessions, all members of the EP have the right to speak and be addressed in all official languages. In smaller-scale meetings (committees, delegations), this is reduced to only the "official languages used and requested by the members and substitutes of that committee or delegation" (European Parliament 2004:66, cf. also European Parliament 2006).

The language ideologies that traditionally "guide" institutional attitudes towards languages and multilingualism also differ and are influenced by the character of the focal institutions (cf. Krzyżanowski \& Wodak 2010, and above). Not (directly) accountable to national audiences, the CEC's internal linguistic practices remain guided by ideologies rooted in the principle of INTERNAL INSTITUTIONAL EFFICIENCY and which can be summarized as A SEARCH FOR A COMMON DENOMINATOR, that is, a language/code shared by most of the participants in the internal meetings where an interpretation service is usually unavailable. The common denominator, as we 
were able to record, is established by the CEC's traditional lingua francas, that is, French and English. At the EP, where the key ideology is that of the EXPRESSION OF NATIONAL STANDPOINTS (at least in the observed semipublic and public contexts), multilingualism is in most cases driven by the MEPs' need/will to express their political and policy positions from a national standpoint in their national language, which is facilitated by the interpretation service present in all plenary and semiplenary meetings. Such institutionally specific language ideologies not only define the macrolevel (i.e. overall) linguistic repertoires of the EP and CEC, but also penetrate their microlevel linguistic practices (cf. IN-DEPTH ANALYSIS OF SELECTED MEETINGS (CASE STUDIES)).

\section{Ethnographic fieldwork at the CEC and the EP}

The material analyzed below comes from a sequence of fieldwork sessions conducted at the CEC and EP throughout 2009, when we visited the CEC on four and the EP on two occasions, with each fieldwork session lasting one working week. During the fieldwork we primarily conducted ethnographic observations, mainly of publically inaccessible institutional spaces at the CEC, and plenary and semiplenary meetings at the EP. At both institutions, we also conducted twenty-two extended semistructured interviews (of ca. one hour each) with midand high-level officials responsible for shaping the European Union's language regulations and policies. While those interviews are not analyzed in detail in this article, they serve as a source of important contextual knowledge, informing our analyses of the meetings presented below.

Our ethnographic observations took place according to a set of predefined guidelines that were structured according to our research questions (cf. INTRODUCTION: Aims AND oBjectives). The guidelines covered salient dimensions of linguistic interactions such as:

- Linguistic PROFILES (REPERTOIRES) OF THE MEETINGS: number and variety of languages used throughout the meetings;

- FREQUENCY OF CODE-SWITCHING: convergence/divergence of CS with turn-taking, code-persistence over turns;

- Topic-Related Vs. AdDRESSEe-Related language ChOICES;

- LANGUAGE CHOICES AND CS vs. DEGREES OF FORMALITY AND INFORMALITY: for example, variation between phases and stages of the meetings (before/during/after official proceedings), between different elements of physical spaces (e.g. front rows vs. back rows);

- Thematization of issues Related to multilingualism and language use, that is, METACOMMUNICATION ON LANGUAGE: in relation to topics under discussion, participants, the flow/ efficiency of communication.

All categories were carefully documented in our fieldnotes during the meetings and discussed/supplemented at the end of each working day. Each meeting was 
observed by at least two researchers, with each of them focusing on different aspects of the interactions. For example, while one of the researchers was focusing on aspects of linguistic profiles of meetings and CS, the other was taking notes and (inasmuch as possible) pictures/sketches of the situational contexts (cf. Figures 1-3 for examples). After the meetings, the researchers discussed their notes in order to supply missing information and exchange their conclusions of the interactions observed.

At the CEC - twenty-eight observed meetings in total-we had access to several Directorates General including DG Translation (DGT, the Commission's largest Directorate General, which provides translation services for all types of CEC written communication), DG Interpretation (DG SCIC, providing interpreting services for the majority of EU organizations except the EP) and the Secretariat General of the Commission (SEC-GEN). Especially at the DGT and SCIC, we observed "internal" meetings at various hierarchical levels (from top management, through directorates, down to the level of departments and units) as examples of how multilingualism functions in closed institutional spaces, that is, BACKSTAGE (Wodak 2009). At the CEC, the average duration of the observed meetings was about ninety minutes.

Our overall quantitative quantification of the observed multilingual practices in the CEC and the EP (cf. Figures 4-5; cf. Krzyżanowski, Wodak, \& Forchtner 2009 for further details) points to both similarities and differences between the linguistic repertoires of the two organizations. At the CEC, the prominent role of Europe's new lingua franca was obvious: we concluded that English was exceptionally strong - even in comparison to French, the "traditional language" of the CEC. While English was clearly the dominant language of the EP as well, other languages were more prominent than in the CEC, due to the presence of an interpretation service and the meeting chairs who traditionally use their national languages.

\section{IN - D E P TH ANALYSIS OF SELECTED MEETINGS ( C A S E S T UDIES)}

In this section, we provide three extracts from our data (extracts (1) and (2) from a meeting at the CEC; extract (3) from a meeting at the EP). They are analyzed with respect to the sociopolitical and organizational contexts and immediate co-texts in which they occurred and the different types of CS that can be distinguished. We focus primarily on instances of language choice and CS and are thus necessarily forced to neglect many other possibly interesting linguistic-pragmatic aspects of these meetings (such as argumentative patterns in relation to the wider sociopolitical agenda of the EU and their subcommittees; see Wodak 2009). In our conclusions, we provide a first taxonomy of factors that may facilitate CS of various kinds and interpret our quantitative and qualitative results related to our research questions and claims as put forward before. 
RUTH WODAK

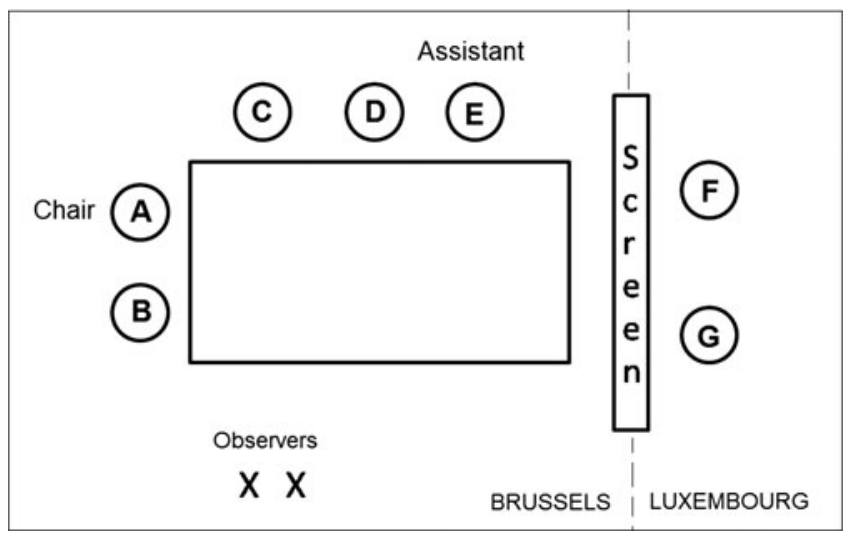

FIGURE 1. Example of the physical set-up of a video conference CEC meeting.

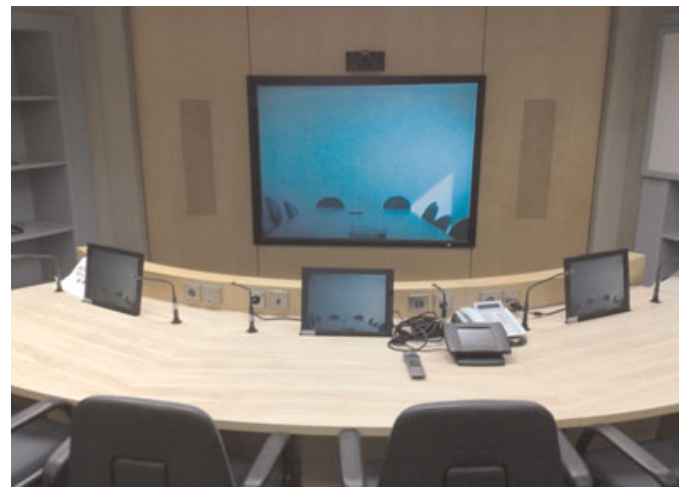

FIGURE 2. Image of a typical CEC video-conference/meeting room.

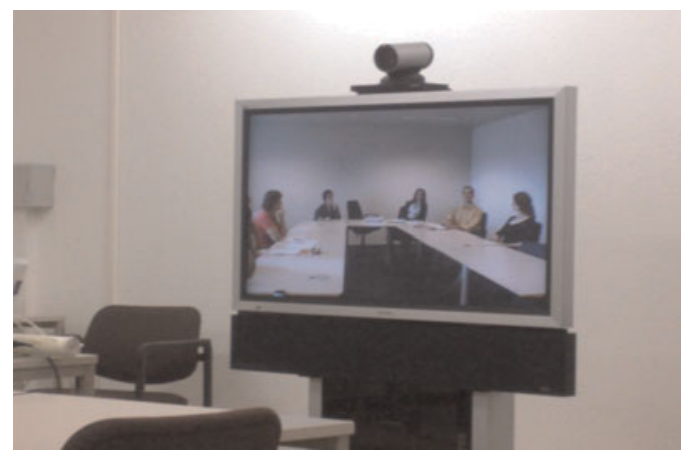

FIGURE 3. Image of a typical CEC video-conferenced meeting in progress. 


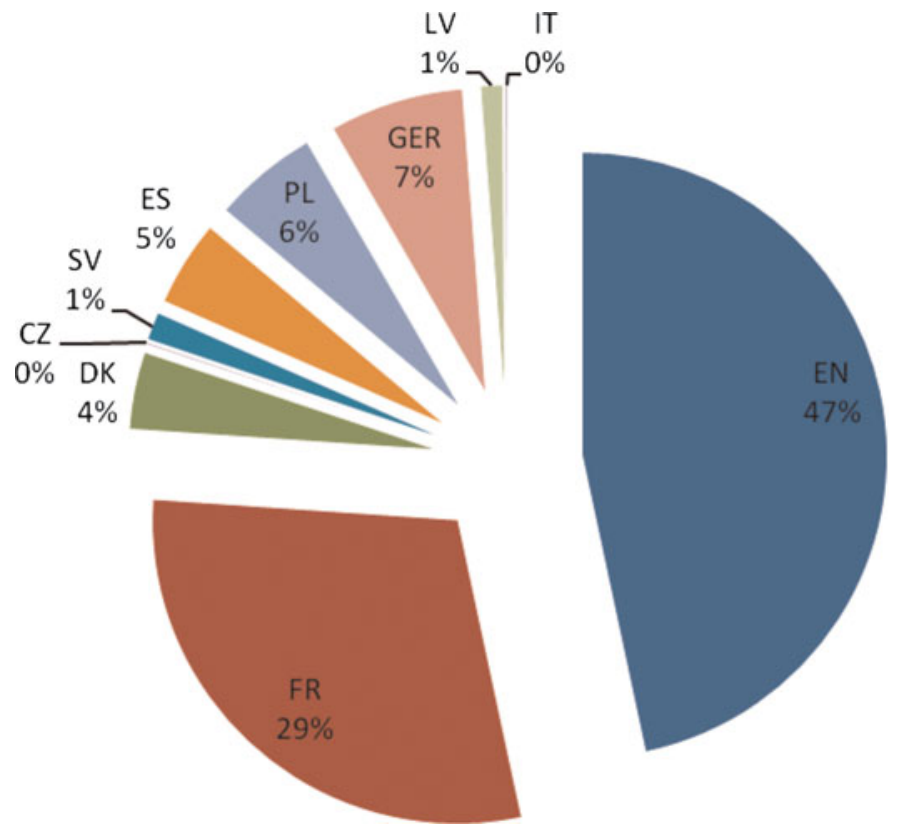

FIGURE 4. Overall (rounded) percentage of languages in the observed meetings at the CEC.

(1) CEC: "Swine flu" and metacommunication on language

217 M1: N1H1 - yeah.

218 M4: That's the only official name of it basically.

219 M3: It's maybe not sexy in the papers.

220 M4: But there we are.

221 F1: Newspapers of course call it swine flu err but it depends on the country

222 some don't because it doesn't sound very [fantastic.

223 M4: [Belgian Belgian French err radio

224 they changed from la grippe Mexicaine to la nouvelle grippe.

225 M1: Obscene.

226 M4: La nouvelle grippe.

227 F1: La nouvelle grippe

228 M4: That's what they called it on public radio la nouvelle grippe I don't know

229 well to my knowledge it was Mexican (0.5) they stopped a couple of

230 things.

231 M3: La grippe voilà ((laughter)).

'the flu-there you go.'

232 F1: Je pense que le problème maintenant la grippe (0.5) Mexicaine c'est

233 finie $(\uparrow)$ non.

'I believe that the problem related to the Mexican flu is now solved.'

234 M1: I do I.

235 F1: Yes M1 yeah.

236 M1: I do have... 


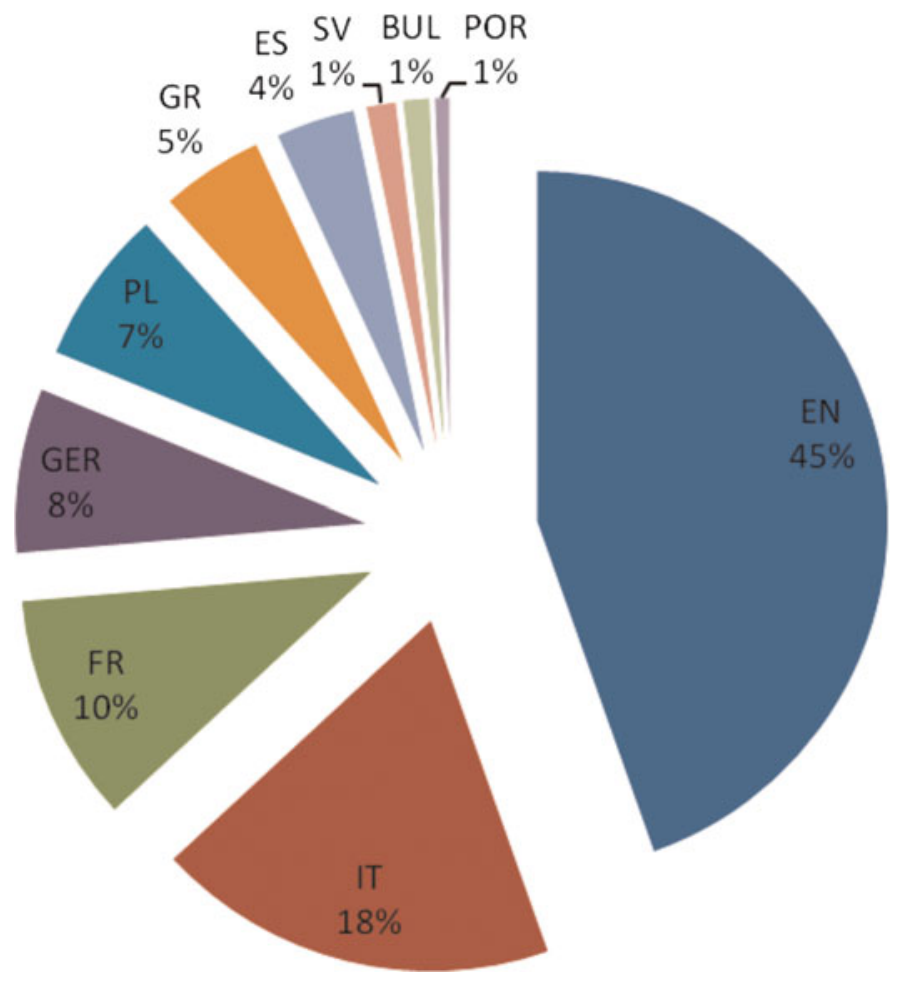

FIGURE 5. Overall (rounded) percentages of languages used in meetings observed at the EP.

The meeting is split between Brussels (nine participants) and Luxembourg (three participants) and thus video-conferencing is used whereby F1, the meeting's female chair, is situated in Brussels. F1 is a native speaker of German who showsas we were able to observe throughout — a slight preference for French as her second language. In contrast, M1, situated in Luxembourg, is a native speaker of English with some knowledge of French. Also situated in Luxembourg is M3, a native speaker of French. Like M1, he shows a strong preference towards his mother tongue throughout the meeting, as does F3 (extract (2)), the third participant in Luxembourg, who is a native speaker of French with a rather limited command of English (which became obvious from our extensive observations). M4 is in Brussels and is a native speaker of Polish. He has a rather passive knowledge of French and his preferred second-language choice is English. All five are actively participating in the meeting.

In this brief extract, the participants discuss intensely how to label "swine flu" with a standardized and not negatively connoted name, which, however, should 
be easy enough for the media and laypersons to remember and cite and which should also not consist only of a quasi-formula, such as H1N1 (line 217). This was one of many METADISCUSSIONS ON TERMINOLOGY, language for specific purposes and expert language with which this committee is confronted. The chair is F1, whose second language is French and who is, accordingly, responsible for one of the CS (line 232) when accommodating the preceding speaker (M3), although the co-text illustrates that she did not make a CS when the French names "la grippe Mexicaine" and "la nouvelle grippe" were mentioned (lines 224-29). In these six lines, the French labels were tried out for their resonance and repeatedly uttered as a quote from the French/Belgian media by different speakers (M1, M4), although the exchange remained in English.

It is also remarkable that the discussion starts in English, that F1 makes a first important statement related to the label "swine flu" in English (line 221), and establishes the reasons why a different and a more neutral label should be found (i.e. not "la grippe Mexicaine"), "because it doesn't sound very fantastic," which manifests a clear translation from German (for example, "nicht so toll") which would probably not be used by a native English speaker in this context in this form. After M1 responds in English, F1 switches to English again seemingly out of reasons of efficiency and not for other ideological language reasons.

In this extract, we thus encounter a brainstorming discussion consisting of spontaneous talk with interruptions that - as in line 223 - serve to elaborate the argument put forward by F1 in lines 221-22. This corresponds to the "cyclical pattern" of meetings identified by Holmes \& Stubbe (2003): the chair F1 does not control the turn-taking in any formal way apart from setting the agenda and the relevant argumentative standpoint (lines 221-22), which is then adopted by all other participants. Power and control are mitigated but not invisible. In Auer's terms, we could identify the CS in line 232 as being "participantrelated"; according to Heller's framework, the power of the chair is obviously also relevant for language choice here. However, both the function of genre (brainstorming meeting; searching for standardized terminology in contrast to, e.g. media definitions) and the broader context of this committee in the CEC, with efficiencydriven English language use, are salient for language choice and occurrences of CS. The end of this episode (234-36) is marked by a shift back to English motivated by M1. F1 accommodates this CS by agreeing with M1 and by simultaneously maintaining her role as chair and continuing to manage the flow of the meeting.

(2) CEC: Technical issues - group jargon?

$\begin{array}{ll}266 & \text { F1: } \\ 267 & \text { Yeah I've noted some more problems also with other applications like } \\ 268 & \text { Outlook and things like that but this seems to be err a result of that so we } \\ 269 & \text { have to all BEAR with with the Informatics people on this one (.) ok I think } \\ 270 & \text { we have exhausted this point (.) alors F3 a des mots for the welcome pack } \\ & \text { errm j'ai err [vu ton email. } \\ \text { 'well, F3 has some words about the welcome pack-I have seen your email.' }\end{array}$


F3: Errm oui il y a des nouvelles.

'Yes, there is some news.'

F1: J'ai err fait quelques err quelques changements linguistiques mais j'étais tellement err bogged down par par tous les préparations pour la porte ouverte dont on va parler après que je n'ai pas encore réagi officiellement disons mais err peut-être tu veux dire à tout le monde un petit peu. 'I have made some linguistic changes but I was so overwhelmed by all the preparations for the open day about which we will talk later that I have not yet reacted officially - thus - but maybe you want to say something to everybody.'

F3: Oui il y a deux jours on a reçu le commentaire de le err l'unité formation ils sont tels minimes ils ont accepté pratiquement tous les textes sur la formation que nous avons proposé à eux simplément ils ont parlé de err de de la rubrique err what do I need to know err about my first days in DG errm (1.0) je je préparais cette cette réponse et err team doit encore [...] 'Yes, two days ago, I received a comment from the 'formation unit', these are the minutes, they have basically accepted all the texts on the construction which we proposed; they talked simply about the rubric "what do I need to know about my first days in DG' I have prepared an answer and the team has still to [...]'

In this extract (of the same meeting) F1 starts a new topic from the agenda, the discussion of some problems related to e-mail and IT; she then turns to F3, a native speaker of French, and switches to French, accordingly (lines 269-70). This instance of CS is clearly participant-related, marked by the (familiar) personal pronoun $t u$ whose use is possible in French (but not in English). F3 starts to introduce her report after having being asked for this by F1, who interrupts and explains why she had not been able to help more with these problems because she was overwhelmed ("bogged down," line 273) by the preparations for the open day ("porte ouverte"). This interruption has at least two functions: it facilitates the subsequent turn by F3; and it justifies and elaborates on the reasons why F3 is handed the turn. F1 remains in French as this is still part of her appeal to F3 to give more details on the website and related issues.

F3 then continues with her report and lists several problems that have been noticed with the so-called "welcome package" on the DG's website, and a link on the website labelled "What do I need to know about my first days in DG" (line 279). Of interest are the instances of LANGUAGE FOR SPECIFIC PURPOSES (LSP) and the group jargon of this community of practice. We encounter instances of BORROwING here ("bogged down"), that is, an English colloquial term is woven into the otherwise French flow of speech. This instance does not lead to a CS. Moreover, we detect two instances of English terminology that seem to be used ubiquitously, namely the two labels on the website. Moreover, as part of the insider-jargon (see Born \& Schütte 1996 for a description of Eurospeak), F3 uses a calqued translation of 'open day', namely "porte ouverte", which, unlike the English term used across languages spoken in the EU organizations, is rarely used in French. This might again be an example of her linguistic competence in French. 
In contrast to (1), extract (2) illustrates another instance of efficiency as language ideology, that is, using the language in which one's linguistic competence is best. In this case F3, as a native speaker of French, seems to prefer French, and the chair invites this language choice although she herself, as a native speaker of German, usually remains in English throughout the entire discussion.

This instance of CS could be explained in various ways: as competence- and preference-related, that is, F3 does not speak English well enough; as a manifestation of hegemonic multilingualism (French might still be evaluated as being more prestigious than English in the CEC as some of our interviews suggest); or it might be the case that English and French are the only two languages that are shared in this community of practice, and are thus comprehensible to everybody. Moreover, language choice in (2) might also be co-determined by preferred modes of self-presentation, performing one's expertise, and substantiating the group's identity. ${ }^{7}$ Finally, some CSs might in this case be related to the topic under discussion (IT issues), as an instance of LSP.

(3) EP: Power struggles via language choice

1 SP1 (MEP, ES): Dziękuję bardzo. Thank you very much

'Thank you very much.' $\mathrm{Mr}$ (.)e-eerm kind President. aam I do agree with Mrs Harkin that there are elements in the Onesta and indeed in the corporate report that might enter and that we shall vote next week in Hungary that might set a new context for this discussion. Paso porque estoy hablando en ingles [unread 2.0] ((laugh)) Paso al castellano. 'I'll pass because I'm speaking in English [...]' ((laugh)) 'I'll switch over to' Castillian.

Venga. [...] [continues in Castilian for 1:40 min] 'OK. Let's see [...] ].'

Bueno, podría sí más que el contenido pero sí que buscaría tener esta 'Well, it could be more than the content but I would like to have this' discusión a la próxima legislatura que en todo caso va a plantear muchas cosas. Gracias. 'discussion (around the time) of the next legislature which will, in any case, raise a lot of things. Thank you.'

SP4: (chair, MEP, PL): (1.0) Pani Sinnott 'Mrs. Sinnott'

SP2: (MEP, IRL): I will be very brief, I have never [...] [continues in English for $0: 22 \mathrm{~min}]$

SP4: $\quad$ (chair, MEP, PL): (3.0) Sir Robert

SP3: Chairman, eem I think I am not (unreadable 2.0) I am I am slightly deterred am by what Miss Harkin said because (.) as I recall when am-the Socialist group and the EPP group produced this report it was a working document (.) we produced it am-am by EVEning right and it was tabled to the committee for discussion the next day so it was deliberately not designed to exclude in any way shape or form

SP1:

Oh no ((laughs)) 


\section{RUTH WODAK}

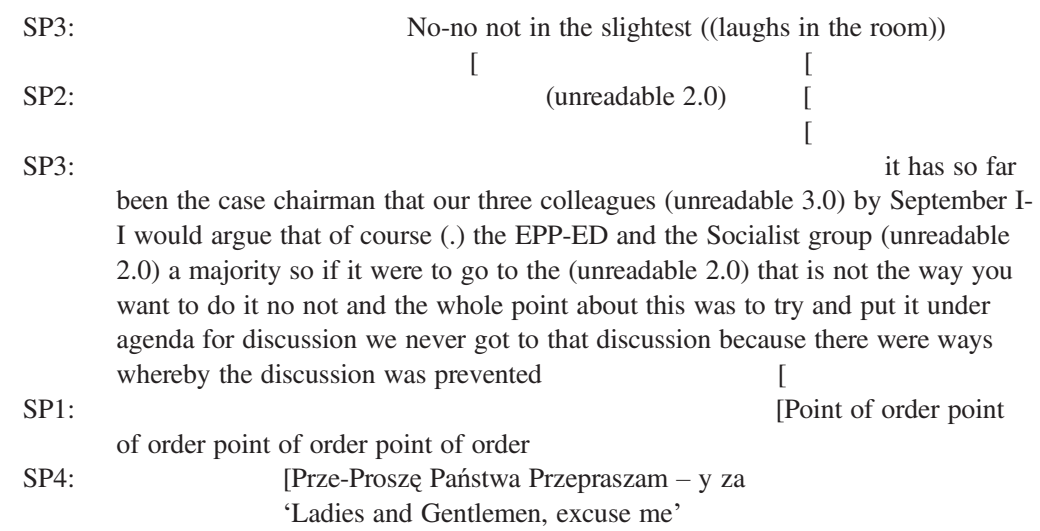

been the case chairman that our three colleagues (unreadable 3.0) by September II would argue that of course (.) the EPP-ED and the Socialist group (unreadable 2.0) a majority so if it were to go to the (unreadable 2.0) that is not the way you want to do it no not and the whole point about this was to try and put it under agenda for discussion we never got to that discussion because there were ways whereby the discussion was prevented

[ [Point of order point

of order point of order point of order

[Prze-Proszę Państwa Przepraszam - y za

'Ladies and Gentlemen, excuse me'

Proszę bardzo

'Well - Please'

SP1: I'm SORRY, but I would request that Mr Atkins APOlogizes to the Secretariat and APOlogizes TO these members, saying that the Secretariat got to know. We know how to read; we have our own facts here. I really think I really think I really think that you should apologize to the Secretariat and apologize to members. This is - We have seen enough insulting of the high (unread 1.0) of this committee

[BUT Yeah. No (0.5) it is important

$[\mathrm{Hm}-$

SP4: $\quad$ [So-hm-sorry (.) proszę państwa proszę państwa [...]

'excuse me ladies and gentlemen excuse me ladies and gentlemen [...]'

[Chairman, I was I was speaking before that $[\ldots]$

[Zaraz sir Robert może być przyję ty tylko za zgodą WZYSTKICH on 'in a minute Sir Robert — can be accepted only upon agreement of ALL' nie może być ponieważ on nie wynika w sposób oczywisty z regulaminu [...] [continues in Polish] (unread 1.0) proszę bardzo ostatni raz jeszcze bo [...] (unread 1.0) 'ok so for the last time please one more time because $[\ldots]$ '

[Ch-Chairman I was

stąd do yy-do-do (1.0) yy David Hammerstein Minz potem Sir Robert [...] 'so we move from here to to (1.0) David Hammerstein Minz and then Sir Robert $[\ldots]$ '

SP4:

$$
\text { [ }
$$

Hammerstein-Minz potem Sir Robert

[Ch-Chairman

[zaraz David

'Just a second David'

'Hammerstein Minz and then Sir Robert'

SP3: [Sir, Chairman I was speaking before I gave way to a [unread 1.0], surely I can be allowed to complete my remarks, please. (1.0) Chairman, I have never set out, and neither has the Socialist group, to make this anything other than an opportunity for intellectual judgement. [...] we have never had the chance to debate this document, so to suggest that we somehow are responsible for that-it's not my responsibility, it's been tabled on numerous 


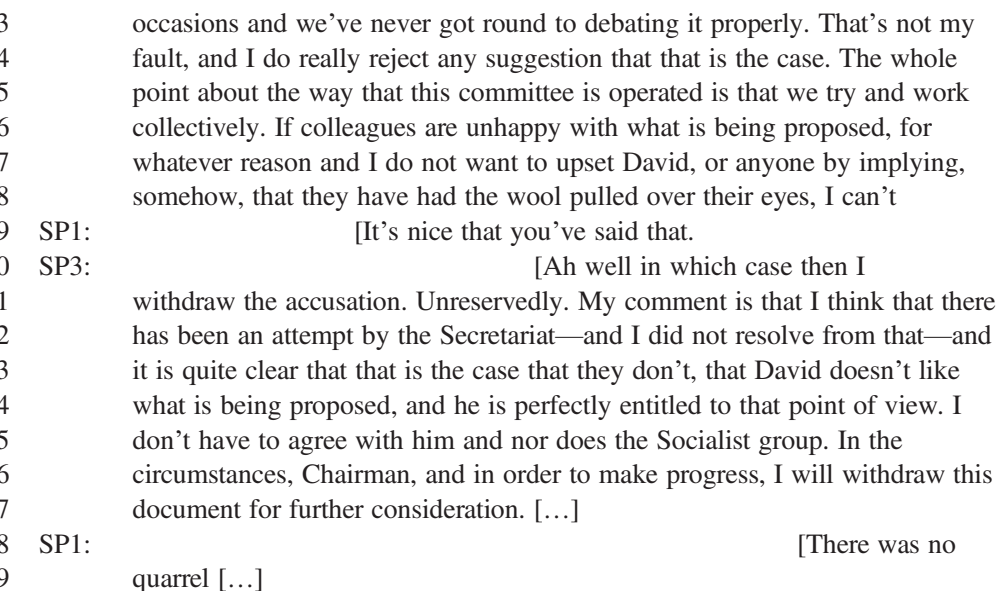

This extract comes from an EP Committee on Petitions meeting that dealt mainly with petitions on environmental issues in various European countries and apparent violations of competition rules (the content of the meeting is fully available online $^{8}$ ). In the passage analyzed below, four speakers are active: Speaker 1 (SP1, male) is a Spanish MEP from the European Green Party 2004-2009, while SP2 is a female Irish MEP from the Independence/Democracy Group and vicechair of the committee. SP3 (male) is a British MEP since 1999 and from the European People's Party (Christian Democrats) and European Democrats (until 2009). Finally, SP4 (male) is a Polish MEP, chair of the committee (and of the meeting) from the Union for Europe of the Nations Group.

In EP committee meetings the chair has a dominant role and is in charge of turntaking. Every speaker is called by the chair and, after each turn, the chair hands out the next turn, according to the list of registered speakers. MEPs are encouraged to use their native language when speaking - a factor that constructs the EP as an inherently monolingual organization and not a multilingual space as frequently claimed: speakers usually stay within their native language (due to the presence of an interpretation service) and do not interact in a multilingual manner as presented, for example, in (1) and (2) However, in specific contexts (such as when conflicts arose), MEPs often switch to English to emphasize their opinions, which implies the perceived larger symbolic capital of English ${ }^{9}$ (and its related language ideology), as suggested by our concept of hegemonic multilingualism (see above). Moreover, it could be the case that MEPs want to avoid use of the mediated language offered via interpretation in conflictual episodes.

Extract (3) illustrates one of the very rare instances in the recorded EP committee meetings where a conflict arises with spontaneous interruptions, raised voices, and manifold CS. The institutionalized turn-taking mechanism is temporarily abolished; SP1 and SP3 get involved in a struggle about procedures of the Petition 
Committee and a draft policy paper that manifests political differences in opinions and different loyalties towards the Secretariat (i.e. the CEC representative Mrs. Harkin who explained her take on the proposed document in a previous statement). The chair of the Committee is a Polish MEP (SP4) who attempts to intervene into this conflict five times (lines 36, 38, 46, 52, 55) by interrupting SP1 who overrides the chair's speakers list and takes the floor without being invited to do so. He explicitly disagrees with SP3 on the function of the secretariat and their reported activities as well as on the functions of the draft document and the defined scope of the committee as such (lines 1-10, 40-45). SP1 thus interrupts SP3 twice by interjecting disagreement ("No," line 21); repetition of "point of order" (lines 34-35), and twice, after SP3 proposes an alternative approach to the drafting process, in agreement and support ("It's nice that you have said that" (line 69); "There was no quarrel" (lines 78-79). The latter comment marks the end of this confrontational debate and implies a redefinition of this episode as rational and "no quarrel" after SP3 justifies himself by emphasizing that he is not to blame for the draft proposal nor is the Socialist Party to blame for the procedures.

Apart from this brief insight into the highly political agenda of, and debates in, this committee, it is also important to analyze the CS in SP1's turns as these instances of CS relate to the political agenda and to the mode of self-presentation performed by SP1, partly intentionally as indicated in lines 1, 5-6. There, he first addresses the chair in Polish, a polite participant-related way of addressing the chair (who is Polish), yet switches to English, relating to the former speaker, Mrs. Harkin, and then explicitly comments on his switch to Spanish in line 5 as this is both his preferred and expected language in this context (official language regulations) in the EP.

After SP3 puts forward his standpoint and explains the nature of the draft document from his and the Socialist Party's perspective, SP1 becomes increasingly involved, emotional, and raises his voice — and switches to English again: this time, first, by loudly interjecting "No" in line 21 ; then, a second time, by interrupting in lines 34-35 ("point of order"); and then, a third time, by interrupting the chair in line 40, by first hedging and introducing this interruption with an apology ("I'm sorry") and then continuing with a strong request that SP3 should apologize to the secretariat. In this turn (lines 42-45), he aggressively attacks SP3 by claiming that SP3 has insulted the committee and the secretariat. This CS allows for several interpretations: it might be the case that SP1 accommodates SP3 and thus chooses English over Spanish. Secondly, it might be the case that such brief interjections (in the genre of parliamentary debates) might even not be translated if not voiced loudly and in English (see Ilie 2010), and thus not be registered by SP3. It also might be the case that - due to his emotional involvement-SP1 would like to confront SP3 directly and not depend on mediated communication which he would be unable to control (i.e. delayed interpretation from Spanish into English). Moreover, it might be the case that the CS to English indicates the greater symbolic capital of English. Very likely, more than one factor co-determined this CS. This 
specific CS can only be interpreted and explained by taking into account the genre, the co- and context, the topic under discussion and its trajectory throughout a range of meetings (intertextuality), and the power dynamics of the specific interaction as well as the immediate conflict - which substantiates our critical discourse analytic and sociolinguistic approach. Of course, only more instances of a similar kind would make it possible to rank the range of factors in terms of their possible impact on language choice.

The chair succeeds in ending SP1's attack by interrupting in line 46 (and not letting SP3 cut in in line 47). In this way, the chair regains control over the discussion and starts his longer statement, thus moving the discussion on to procedural matters. The chair sticks to Polish throughout his attempts to control the conflict (and the turn-taking). SP3 explicitly asks for the opportunity to finish his statement as SP1 had taken the floor away from him before. SP3 justifies his previous actions and opinions, and then explains why he had requested that the committee enter into a debate (because "we've never got round to debating it properly", line 63). Finally, he concedes that other MEPs might have different opinions ("I do not want to upset David, or anyone by implying, somehow, that they have had 'the wool pulled over their eyes'," lines 67-68) and proposes an alternative procedure while reemphasizing some points of disagreement ("I don't have to agree with him and nor does the Socialist group. In the circumstances, Chairman, and in order to make progress, I will withdraw this document for further consideration," lines 74-77), in order to save face. This is, as mentioned above, supported and accepted by SP1, who continues speaking in English.

This episode of spontaneous debate is characterized by ten CSs. First, for politeness, SP1 accommodates the Polish chair; he continues in English, due to the previous speaker and the other MEPs whom he attacks; he then shifts into his native language of Spanish. However, in the argument, he remains in English throughout until the conflict is resolved. The chair (SP4) continues in Polish in his attempts to control the debate and the turn-taking while SP3 uses his native language (English) throughout, both according to the code of conduct. Thus, SP1, obviously conscious of his language choice as the meta-comment at the outset indicates, is the only one who deviates from normal procedures.

\section{O N C L U S I O N S}

In general, our analysis has illustrated that different MULTILINGUALISMS are being simultaneously performed in the EU investigated contexts. Our qualitative analysis, based on extensive ethnography, manifests the repertoire of different kinds of, and facilitating factors for, language choice as well as the intricacies of the language regime in a transnational organizational entity such as the EU.

In our analysis, we have observed a CONTINUUM OF (MORE OR LESS) MULTILINGUAL PRACTICES that are highly CONTEXT-DEPENDENT and serve a range of manifest and latent functions, such as: emphasizing the chair's power or challenging it; 
accommodating the previous speaker's language choice or relating to the specific agenda under discussion; struggling to win a debate; and so forth. LANGUAGE CHOICE thus depends on manifold factors, which are related to efficiency and/or (language-)ideological factors. Moreover, LANGUAGE FOR SPECIFIC PURPOSES (professional jargon) comes into play as well as diverse PEER-GROUP SOCIOLECTS as manifestations of communities of practice in organizations. Most importantly, the GENRE of interaction (frontstage or backstage; spontaneous brainstorming or highly regulated interaction) and the specific COMMUNITY OF PRACTICE (i.e. the history of topics and meetings) seem salient (see also Johnstone 2008). As our analysis clearly demonstrates, the genre of the meetings, the language regulations of the particular organizations, the interactional dynamics, and the topic play a decisive role in determining the organization of interactions, turn-taking, and distribution of power. POWER thus becomes manifest in access to the floor, choice of language, choice of topic, and regulation of the macroflow of interactions.

We have illustrated that different multilingual practices are implemented inside the EU organizations, far beyond a strict "mono vs. multilingualism dichotomy." Language choice and CS depend on a plethora of context-dependent factors. Hence, it is salient to account for the characteristics of each meeting type, as these entail specific codes of conduct, turn-taking procedures, and hierarchies of speakers. Moreover, we have distinguished a set of facilitating factors for CS to occur, apart from, and interacting with, structural constraints such as the respective codes of conduct and language regulations that set the stage for the implementation of multilingual practices:

- Co-text Related factors, such as the specific topic and technical jargon, the language of the preceding speaker, and politeness phenomena;

- GENRE-RELATED FACTORS, such as the macro-structure of the respective meetings and their official manifest functions;

- LANGUAGE-IDEOLOGY RELATED FACTORS, such as language choice due to the perceived prestige of a language;

- POWER-RELATED FACTORS, such as the intention to win an argument, attempts to control the debate, gain the floor, set the agenda, and so forth;

- PERSONALITY- AND RELATIONSHIP-ORIENTED FACTORS, such as preferred language choice, modes of self-presentation (on frontstage and backstage), group dynamics, and traditions of a community of practice.

There might be, of course, other reasons that would require more in-depth qualitative context-dependent and text-oriented research. Most importantly, it is obvious that CS is multidetermined and that one theoretical approach per se does not suffice to explain the manifold instances of CS in such a complex multilingual and transnational context as the EU's organizations. Moreover, modes of self-presentation and identity construction have proved salient: the choice of a specific language, both consciously and subconsciously, does indeed reveal the values and attitudes 
attributed to specific languages. Different kinds of institutional, national and personal identities could be detected: administrative-institutional ones (CEC) and political-institutional ones (EP).

Our multilevel (macro) contextual analysis-integrated with a sequential (micro) analysis of texts - helps in dealing with the intricacies of multilingual practices by taking the range of factors into account, which co-determine and facilitate code-switching. These factors are located on several levels of language and dimensions of context from language regulations to their implementation; from text to discourse; from socio-political contexts to the co-text of each utterance; from the overall history of specific committees and their participants to a specific topic; and from explicit official hierarchies and defined roles of power to immediate negotiations of power-in-interaction. 
(.)

$(6.0),(8.0),(9.0)$

(unread. 6.0)

[

Mhm. Eeeee

((leans

((laughs))

THIS

$(\uparrow)$

$(\downarrow)$

$[\ldots]$ short pause (1 second or less)

longer pause (six seconds, eight seconds, nine seconds duration)

unclear elements of speech

overlapping speech

paraverbal elements

back)), nonverbal behavior

stressed/accentuated element of speech

rising intonation (if significant)

falling intonation (if significant)

omitted parts of text/utterance

If the original language of the text/utterance was other than English, a translation is provided in the interlines.

\section{N O T E S}

*We would like to thank Dik Bakker, Wolfgang Ulrich Dressler, Paul Kerswill, Mark Sebba, and the late Anna Siewierska for their useful comments on the first drafts of our article. We are also very grateful to Monica Heller and two other reviewers from whose input the final version of this article has benefitted greatly. Of course, responsibility for any shortcomings remains our own.

${ }^{1}$ This article draws on research conducted within an Integrated Project, DYLAN (Language Dynamics and Management of Diversity), funded by the European Commission under its Sixth Framework Programme (Contract No.: 028702; www.dylan-project.org).

${ }^{2}$ In our research, we also draw on a number of studies of talk in the workplace and other organizational settings (cf. Bargiela-Chiappini \& Harris 1997; Menz 1999; Sarangi \& Roberts 1999; Wodak 2000; Holmes \& Stubbe 2003; Iedema, Degeling, Braithwaite, \& White 2003; Mondada 2007).

${ }^{3}$ But note Gumperz's (1982:84) explicit discussion of the knowledge of speakers in order to 'distinguish meaningful code juxtapositions from mere random or idiosyncratic alternations and to draw appropriate conversational interferences'. Auer's criticism is also directed against Fishman's (1965:56-8) variables that determine language choice (cf. also Myers-Scotton 1993; Myers-Scotton \& Bolonya 2001).

${ }^{4}$ This is directed against classical sociolinguistic assumptions, as formulated in works by Gumperz and others (Blom \& Gumperz 1972; Gumperz 1982).

${ }^{5}$ But note Gumperz's (1982:84) explicit discussion of the knowledge of speakers in order to "distinguish meaningful code juxtapositions from mere random or idiosyncratic alternations and to draw appropriate conversational interferences."

${ }^{6}$ In her recent work, Gal (2010) claims that the EU has now become a typical late-modern socioLINGUISTIC REGIME, which, though officially multilingual, conceives of its multilingualism in a rather limited way. Thus, the EU could indeed be considered a "top down regime of multilingual standardization that tries to manage increased diversity in the same ways nation states managed non-standard varieties" (Gal 2010).

${ }^{7}$ To substantiate these interpretations, more data analysis would be necessary—we have to leave this for future research.

${ }^{8}$ See http://www.europarl.europa.eu/meetdocs/2004_2009/organes/peti/peti_20090430_1500.htm. 


\section{THE INTERPLAY OF LANGUAGE IDEOLOGIES}

${ }^{9}$ This interpretation was offered by the head of the interpretation service in the EP, in an interview conducted on 4 November 2009. We are very grateful to Martin Wooding for his support during our fieldwork at the EP.

\section{R E F E R E N C E S}

Abélès, Marc (1992). La vie quotidienne au Parlement Européen. Paris: Hachette.

(2000). Virtual Europe. In Irène Bellier \& Thomas M. Wilson (eds.), An anthropology of the European Union, 31-53. Oxford: Berg.

_ Irène Bellier, \& Maryon McDonald (1993). An anthropological approach to the European Commission. Brussels: The European Commission.

Alvarez-Cáccamo, Celso (1998). From 'switching code' to 'code-switching': Toward a reconceptualization of communicative codes. In Peter Auer (ed.), Code-switching in conversation: Language, interaction and identity, 29-50. London: Routledge.

Ammon, Ulrich (2006). Language conflicts in the European Union. International Journal of Applied Linguistics 16(3):319-38.

Antaki, Charles, \& Susan Widdicombe (eds.) (1998). Identities in talk. London: Sage.

Auer, Peter (1998). Introduction: Bilingual conversation revisited. In Peter Auer (ed.), Code-switching in conversation: Language, interaction and identity, 1-24. London: Routledge.

(2010). Code-switching/mixing. In Ruth Wodak, Barbara Johnstone, \& Paul E. Kerswill (eds.), The SAGE handbook of sociolinguistics, 460-78. London: Sage.

, \& Li Wei (2007). Introduction: Monolingualism as a problem? Multilingualism as a problem? In Peter Auer \& Li Wei (eds.), Handbook of multilingualism and multilingual communication, 1-14. Berlin: Mouton de Gruyter.

Bakhtin, Mikhail M. (1986). The problem of speech genres. In Speech genres and other late essays, 60-102. Austin: University of Texas Press.

Bargiela-Chiappini, Francesca, \& Sandra J. Harris (1997). Managing language: The discourse of corporate meetings. Amsterdam: John Benjamins.

Bellier, Irène (2000). A Europeanized Elite? An anthropology of European Commission officials. Yearbook of European Studies 14:135-56.

Bellier, Irène, \& Thomas M. Wilson (eds.) (2000). An anthropology of the European Union. Oxford: Berg.

Bhatia, Vijay (1993). Analysing genre: Language use in professional settings. London: Longman.

Blackledge, Adrian, \& Angela Creese (2010). Multilingualism: A critical perspective. London: Continuum.

Blom, Jan-Petter, \& John J. Gumperz (1972). Social meaning in linguistic structure: Code-switching in Norway. Language \& Communication 21:23-36.

Boden, Deirdre (1994). The business of talk. Cambridge: Polity Press.

Born, Joachim, \& Wilfried Schütte (1996). Eurotexte. Tübingen: Narr.

Brewer, John D. (2000). Ethnography. Buckingham: Open University Press.

Davies, Charlotte Aull (1999). Reflexive ethnography. London: Routledge.

Duchêne, Alexandre (2008). Ideologies across nations: The construction of linguistic minorities at the United Nations. Berlin: Mouton de Gruyter.

European Commission (2000). Rules of procedure of the European Commission. Official Journal of the European Communities L 308/26 of 08/12/2000.

European Council (1958). Regulation No. 1 determining the languages to be used by the European Economic Community. Official Journal of the European Communities 17, 06/10/1958.

European Parliament (2004). Rules of procedure of the European Parliament. 16th July 2004. Brussels: European Parliament.

European Parliament (2006). Code of conduct on multilingualism adopted by the bureau, 0409/2006. Brussels: European Parliament. 


\section{RUTH WODAK}

Fairclough, Norman (1989). Language and power. London: Longman.

(1992). Discourse and social change. Cambridge: Polity Press.

- \& Ruth Wodak (1997). Critical discourse analysis. In Teun van Dijk (ed.), Discourse studies: A multidisciplinary introduction, vol. 2, 258-84. London: Sage.

Fishman, Joshua (1965). Who speaks what language to whom and when? Linguistique 2:67-88.

Gal, Susan (2010). Linguistic regimes and European diversity. Keynote lecture delivered at the conference "New Challenges for Multilingualism in Europe" 2010. Dubrovnik, Croatia.

Gardner-Chloros, Penelope (2009). Code-switching. Cambridge: Cambridge University Press.

Gobo, Giampietro (2008). Doing ethnography. London: Sage.

Gumperz, John J. (1982). Discourse strategies. Cambridge: Cambridge University Press.

Hammersely, Martyn (1992). What's wrong with ethnography? Methodological explorations. London: Routledge.

Hardy, Cynthia, \& Nelson Philips (2004). Discourse and power. In David Grant, Cynthia Hardy, Clifford Oswick, \& Linda Putnam (eds.), The SAGE handbook of organizational discourse, 299316. London: Sage.

Heller, Monica (1988). Introduction. In Monica Heller (ed.), Code-switching: Anthropological and sociolinguistic perspectives, 1-24. Berlin: Mouton de Gruyter.

_ (1995). Code-switching and the politics of language. In Li Wei (ed.) (2007), The bilingualism reader 2nd edition, 163-176. London: Routledge,

(1999). Linguistic minorities and modernity: A sociolinguistic ethnography. London: Longman.

(2001). Critique and sociolinguistic analysis of discourse. Critique of Anthropology 21

(2):117-41.

(2003). Discourse and interaction. In Deborah Schiffrin, Deborah Tannen, \& Heidi E. Hamilton (eds.), The handbook of discourse analysis, 250-64. Oxford: Blackwell.

(2007a). Distributed knowledge, distributed power: A sociolinguistic structuration. Text \& Talk 27(5-7):633-53.

(2007b). Bilingualism as ideology and practice. In Monica Heller (ed.), Bilingualism: A social approach, 1-22. Houndmills: Palgrave.

Holmes, Janet (1992). Women's talk in public contexts. Discourse \& Society 3/1:31-150.

Holmes, Janets, \& Michael Stubbe (2003). Power and politeness in the workplace: A sociolinguistic analysis of talk at work. London: Longman.

Holzscheiter, Anna (2005). Power of discourse and power in discourse: An investigation of transformation and exclusion in the global discourse of childhood. Berlin: Free University of Berlin dissertation.

Iedema, Rick; Pieter Degeling; Jeffrey Braithwaite; \& Les White (2003). "It's an interesting conversation I'm hearing": The doctor as manager. Organization Studies 25:15-33.

Ilie, Cornelia (ed.) (2010). Parliaments under scrutiny. Amsterdam: John Benjamins.

Johnstone, Barbara (2008). Studying identity and agency: CDA, interactional sociolinguistics, narrative analysis, grounded theory. In Barbara Johnstone \& Christopher Eisenhart (eds.), Rhetoric in detail: Discourse analysis of rhetorical text and talk, 141-45. Amsterdam: John Benjamins.

Krzyżanowski, Michał (2010). The discursive construction of European identities: A multilevel approach to discourse and identity in the transforming European Union. Frankfurt am Main: Peter Lang.

(2011). Political communication, institutional cultures, and linearities of organisational practice: A discourse-ethnographic approach to institutional change in the European Union. Critical Discourse Studies 8(4):281-96.

(2012). (Mis)communicating Europe? On deficiencies and challenges in political and institutional communication in the European Union. In Barbara Kryk-Kastovsky (ed.), Intercultural communication past and present, 185-213. Frankfurt am Main: Peter Lang.

— \& Florian Oberhuber (2007). (Un)doing Europe: Discourses and practices of negotiating the EU Constitution. Brussels: Peter Lang. 


\section{THE INTERPLAY OF LANGUAGE IDEOLOGIES}

_, \& Ruth Wodak (2010). Hegemonic multilingualism in/of the EU institutions: An inside-outside perspective on the European language policies and practices. In Cornelia Hülmbauer, Eva Vetter, \& Heike Bühringer (eds.), Mehrsprachigkeit aus der Perspektive zweier EU-Projekte: DYLAN Meets LINEE, 115-35. Frankfurt am Main: Peter Lang.

, \& Bernhard Forchtner (2009). Multilingualism in the EU institutions - Working paper 4. Report for the DYLAN Project. Lancaster: Department of Linguistics, Lancaster University.

Kwon, Winston; Ian Clarke; \& Ruth Wodak (2009). Organizational decision-making, discourse, and power: Integrating across contexts and scales. Discourse \& Communication 3(3):273-302.

Martin, James R., \& David Rose (2008). Genre relations. London: Equinox.

Menz, Florian (1999). Self-organisation, equivocality, and decision-making in organisations. Discourse and Society 10(1):101-29.

Mondada, Lorenza (2007). Multimodal resources for turn-taking: Pointing and the emergence of possible next speakers. Discourse Studies 9(2):194-225.

Mumby, Dennis (1988). Communication and power in organizations: Discourse, ideology and domination. Norwood: Ablex.

Muntigl, Peter; Gilbert Weiss; \& Ruth Wodak (2000). European Union discourses on un/employment: An interdisciplinary approach to employment policy-making and organizational change. Amsterdam: John Benjamins.

Myers-Scotton, Carol (1993). Social motivations for codeswitching. Oxford: Oxford University Press.

_ \& Agnes Bolonya (2001). Calculating speakers: Codeswitching in a rational choice model. Language in Society 30:1-28.

Nic Craith, Máiréad (2006). Europe and the politics of languages: Citizens, migrants, outsiders. Basingstoke: Palgrave.

Phillipson, Robert (2003). English only Europe? Challenging language policy. London: Routledge.

Rampton, Ben; Karin Tusting; \& Janet Maybin (eds.) (2007). Linguistic ethnography: Links, problems and possibilities. Special issue of Journal of Sociolinguistics 11(5).

Reisigl, Martin, \& Ruth Wodak (2001). Discourse and discrimination: Rhetorics of racism and antisemitism. London: Routledge.

—, \& Ruth Wodak (2009). The discourse-historical approach (DHA). In Ruth Wodak \& Michael Meyer (eds.), Methods of critical discourse analysis, 87-121. London: Sage.

Sarangi, Srikant, \& Celia Roberts (1999). Talk, work and the institutional order: Discourse in medical, medication and management settings. Berlin: Mouton de Gruyter.

Shore, Cris (2000). Building Europe: The cultural politics of European integration. London: Routledge.

Stubbe, Maria Chris Lane; Jo Hilder; Elaine Vine; Bernadette Vine; Meredith Marra; Janet Holmes; \& Ann Weatherall (2003). Multiple discourse analyses of a workplace interaction. Discourse Studies 5:351-88.

Swales, John (1990). Genre analysis. English in academic and research settings. Cambridge: Cambridge University Press.

van Els, Theo (2005). Multilingualism in the European Union. International Journal of Applied Linguistics 15(3):263-81.

Vine, Bernadette (2004). Getting things done at work: The discourse of power in workplace interaction. Amsterdam: John Benjamins.

Wodak, Ruth (2000). From conflict to consensus? The co-construction of a policy paper. In Peter Muntigl, Gilbert Weiss, \& Ruth Wodak (eds.), European Union discourses on un/employment, 73-114. Amsterdam: John Benjamins.

(2008). Introduction. In Ruth Wodak \& Michał Krzyżanowski (eds.), Qualitative discourse analysis in the social sciences, 1-29. Basingstoke: Palgrave.

(2009). The discourse of politics in action: Politics as usual. Basingstoke: Palgrave.

- \& Michał Krzyżanowski (2011). Language in political institutions of multilingual states and the European Union. In Bernd Kortmann \& Johann van der Auwera (eds.), The languages and linguistics of Europe, 625-41. Berlin: Mouton de Gruyter. 


\section{RUTH WODAK}

\& Michael Meyer (2009a). Critical discourse analysis: History, agenda, theory and methodology. In Ruth Wodak \& Michael Meyer (eds.), Methods of critical discourse analysis, 1-33. London: Sage.

, Michael Meyer (eds.) (2009b). Methods of critical discourse analysis. London: Sage.

Winston Kwon; \& Ian Clarke (2011). 'Getting people on board': Discursive leadership for consensus building in team meetings. Discourse and Society 22(5):592-644.

(Received 13 October 2010; revision received 19 March 2011; accepted 04 April 2011; final revision received 06 September 2011) 